\title{
Local Government and Youth Employment: A case of Nkonkobe Local Municipality in South Africa
}

Skhanyiso Ndhlovu

University of Fort Hare

\section{Costa Hofisi}

North-West University

Email: costa.hofisi@nwu.ac.za

\section{Nicco Schutte}

North-West University

\section{Doi:10.5901/mjss.2014.v5n16p616}

\section{Abstract}

Youth development in South Africa has been of much debate of late given the background of high unemployment and the youth being the most affected. Based on this, this study sought to investigate the effectiveness of the job seekers' program in the promotion of youth employment. The job seekers' program is one of the much needed programs offered by different youth advisory centres in Local Municipalities in South Africa. The Nkonkobe youth advisory centre is one of such centres. The main objective of the study was to assess the effectiveness of the job seekers program towards youth employment in the Nkonkobe municipality. The qualitative methodology used in this study to assess the effectiveness of the job seekers' program was employed through administering questionnaires to the beneficiaries of this program and also to the officials working at the centre while analysis focused on the activities in place under the job seekers program. Findings portray a number of challenges confronting this program. The Nkonkobe youth advisory centre is understaffed and this affects the effectiveness of the programs that the centre offers to the youths. The youths are also not aware of the centre and the programs it offers. The article argues that the job seekers program has not been effective in meeting its target of reducing youth unemployment in the Nkonkobe municipality. With these observations, the article suggests that much emphasis should be put on the outreach program by so doing the youths will be aware of the centre and the opportunities that it offers them. Moreover, the youths should be centrally involved in their own development in order to improve the effectiveness of the job seekers' program.

Keywords: Youth employment, Youth development, job seekers programme

\section{Introduction}

The question of youth development in South Africa has been of much debate of late especially given the background of high unemployment and the youth being the most affected. During the apartheid era, youth development was not of significance to the government because most if not all of the white youth had employment and an opportunity to attain education which is important for employability. This is evidenced by the fact that there was no youth development policy that was geared towards addressing the plight of the unemployed youth. The white population was living in affluence whilst the blacks were living in abject poverty. Most if not all of the blacks lived in homelands which were poorly governed and had little opportunities for employment. The laws governing education were shaped by the apartheid ideology which was instituted through promulgating a number of policies for example the Bantu Education Act of 1954.

The implications of these laws such as the Bantu Education Act of 1953 presented no hope for blacks to get formal employment or to get an opportunity for them to live a sustainable life style. Some of them ended up working in mines while others took up jobs that offered them meager wages. While the industry could absorb some youth for employment others ended up unemployed and had no opportunity for growth in terms of education or entrepreneurship. This situation prevailed for a long period until the advent of democracy in 1994. When the new government came into power there was hope among the poor that the government will redistribute wealth and improve their lives.

Although there has been a presence of the black middle class they are few and there remained pockets of poverty 
especially in rural areas. This is so, because in rural areas there are limited employment and development opportunities for the youth. The plight of youths in rural areas is also exacerbated by the fact that they stay far away from urban settlements where youth development programs seem to be taking place. As such youths in rural areas seem not to have an opportunity to access and benefit from youth development programs. The reason for this may be because they are not aware of youth development programs or they may assume that such programs are not meant for them. One may then wonder how youth in rural areas can develop in such a scenario.

In terms of legislation, the establishment of the National Youth Commission in 1996 through the enactment of the National Youth Commission Act No. 19 of 1996 represents a major commitment by the government to treat the needs of the youth in a serious and comprehensive manner. Moreover, as part of mainstreaming youth development policy and machinery, Cabinet has adopted two important policies. These are the National Youth Development Act No 05 of 2008 and National Youth Policy 2009-2014. These policy changes have resulted in the amalgamation of Umsobomvu Youth fund and the National Youth Commission, giving birth to the National Youth Development Agency. Although this was a noble act to address the challenges and difficulties faced by the youth, the implementation of the Act is laden with anomalies that affect the youth in rural areas. Youth development programs seem to be of benefit towards youths in urban areas.

The government expected that benefits of youth development in urban areas would trickle down to those in rural areas but this is not the case. This was an unfair way of addressing the needs of rural youth. Mandela in Van Zyl Slabbert et al (1994:10) states that the youth of a country are the valued possessions of the nation, without them there can be no future and their needs are urgent. Youths are in urgent need of help in terms of development and these needs cannot be ignored. Development is an ongoing process, it is not about assisting youth in preparation of their future, but also developing youth in their present state (Human Science Research Council 2002). This council further acknowledges participation of the youth in their development instead of them being the recipients of development initiatives.

The Youth Advisory Centres (YACs) have been established by the Umsobomvu Youth Fund. There are currently one hundred and one (111) Youth Advisory Centres in South Africa. Umsobomvu Youth Fund was established in 2001 with authorization to facilitate opportunities for young people to acquire skills, access job opportunities or pursue enterprise initiatives. There is also a youth advisory centre that is up and running in Alice. Youth Advisory Centres are walk in centres where young people are provided with information and support services through one-on-one sessions or group training. These services include basic career and business counselling, life skills workshops and placement or referral services.

According to Global Insight, in 2008, Nkonkobe Municipality had an estimated total population of 131071 and 28 259 households. There are 21 wards within the Nkonkobe municipal area. Approximately $74 \%$ of people living within the Nkonkobe municipal area are poverty-stricken. The majority of the population of Nkonkobe (72\%) resides in both villages and farms and $28 \%$ resides in urban settlements. Africans are the majority in Nkonkobe municipality at $94 \%$. The colored community constitutes the second largest group as they are at $4.5 \%$.

Nkonkobe Municipality enjoys a high literacy rate of $61.0 \%$, which makes the illiteracy rate $39 \%$. Only about $19 \%$ of the population of Nkonkobe resides in urban settlements. This therefore means that the population in the area is rural in nature, with rural: urban ratio standing at approximately 4:1. Nkonkobe municipality has the highest rate of unemployment compared with other municipalities in the Amathole District Municipality. The municipality's unemployment rate stood at $50 \%$ in 2008 (Global Insight, 2008).

The municipality realised a need of establishing a unit that will be dealing with special programs within the municipality. The unit is focusing on programs implemented by youth, the disabled, women and children. It has been identified that young people are the majority of the population of Nkonkobe Municipal area. There is need to develop a youth development plan that will be looking and addressing all the issues pertaining to young people (Nkonkobe Municipality IDP 2007-2012).

The study was aimed at addressing the continued underdevelopment of the youth and in turn the escalation of unemployment faced by youth especially those in rural areas. The issue at hand was that the youth advisory centres are operating in different places in the Nkonkobe Municipality. One such youth advisory centre is operating in Alice a rural town in the Nkonkobe Municipality. This centre has been offering different programs to the youths in Alice and the surrounding rural areas. These programs include the job seekers program, entrepreneurs, career Advisor program, basic Computer Skills, Outreach and information towards developing the youth. The job seekers program is a program that is aimed at helping youths in the municipality with job opportunities. This program was meant to reduce the number of unemployed youths in the Nkonkobe Municipality.

However, despite the continuance of the job seekers program, the majority of youths in the municipality are still facing a challenge of unemployment. According to Stats SA the youth unemployment rate is 2.5 times higher than adults. 
This shows that youth unemployment is a great challenge facing the municipality. What needs to be done then to cater for this challenge? What is causing the ineffectiveness of the job seekers' program in addressing this challenge faced by the youths? Was the problem in the implementation of the program, or with the officials, or the youths themselves? What causes this program to be ineffective?

Poole (2005) criticised development programs offered by youth advisory centres stating that though the programs offer hold great promise for improving the lives and future of the youth, their expectation of these programs are unrealistic. The problem that this study seeks to address is the continued underdevelopment of youth and in turn escalation of unemployment faced by youth especially those in rural areas. The issue at hand is that youth advisory centres have been operating in different places in the Eastern Cape Province and South Africa at large yet the number of unemployed youths seem to be increasing.

The problem of youth unemployment is rapidly assuming alarming proportions. Among South Africans aged 15-24 years, the unemployment rate was $48.1 \%$ in 2009 . The Youth bear the largest share of the unemployment problem; 3.1 million young people between ages of 15-34 are unemployed, accounting for $72 \%$ of the total unemployed. This rate only counts for those young people actively looking for work and not those who have given up looking for work, or who are studying or travelling or otherwise not interested in working. The question of youth unemployment in South Africa is critical and it should be given the urgent attention it deserves.

There has been little attention and resources directed toward training youth, especially those in rural areas, in their respective organizations as the next generation of leaders so as to prevent the social issues that are providing fertile ground for instability. Young people serve as economic cornerstones of Africa's development because they constitute the majority of Africa's population today. The current marginalisation of youth participation in the decision-making processes marks the undemocratic exclusion of the majority of Africa's population and poses a serious threat to social stability.

The socio-economic costs associated with high youth unemployment are significant and cannot be ignored. Other negative consequences associated with youth unemployment are the loss of productive resources and the deterioration of human capital. (Kingdon \& Knight 2000, Levinsohn 2008). The youth are the drivers of economic development in a country. The United Nations has long recognized that the world's youth are valuable resources for the advancement of societies; indeed, they are often the leaders of social, political and technological developments, as well as dynamic agents of social change. However, if they are to take an active role in combating societal problems, then they must be given the right tools with which to work.

The current National Youth Policies in Africa have not responded effectively in mainstreaming youth participation in economic activities that should reduce youth unemployment. The dismal statistics of Youth unemployment, affect mostly countries in the Southern Hemisphere, specifically Africa. It is also a fact that some countries in Africa still lack adequate youth policies. This results in young people being reduced to just being subjects of socio-economic processes and as such are not recognised as social stakeholders with specific interests. The National Youth Development Agency as the custodian of youth development in South Africa has to shoulder the blame from the youth for failing to fight and protect their interests.

Majority of young people in Eastern Cape are not economically active. According to Statistics South Africa (2007) about 168326300 of the Eastern Cape youth are unemployed or not economically active. The research found out that the job seekers program has not been effective when it comes to addressing the issue of youth unemployment. According to the youth, the job opportunities are limited. There is also suspicion among the youth that the distribution of these opportunities is not transparent. In addition, the youth indicated that communication between them and the centre is not effective because sometimes they learn of some opportunities after their deadline whilst other youths are not aware of the centres' existence. Moreover, the centre is understaffed and under resourced. This affects their effectiveness in outreach programs whilst lack of resources like computers hampers their efforts to help the youth with computer literacy.

\section{Research Method}

This study is aimed at investigating the effectiveness of the career advisor program and the job seekers program to the youth of Nkonkobe Municipality who reside in rural areas and the extent to which the Alice youth Advisory centre includes the youth as the beneficiaries in their own development. This study made use of the qualitative method. This is the most suitable method because it espouses elements like why and how and this study also sought to understand whether the youth development programs that are put in place are able to address the plight of the youth in rural areas. Youth in rural areas face additional constraints such as accessibility to services and facilities compared to their urban counterparts.Qualitative researchers aim to gather an in-depth understanding of human behavior and the reasons that govern such behavior. 
The researcher chose qualitative research because this method of research is often used for policy and program evaluation research since it can answer certain important questions more efficiently and effectively than quantitative approaches. This is particularly the case for understanding how and why certain outcomes were achieved not just what was achieved. It also answers important questions about relevance, unintended effects and impact of programs such as: Were expectations reasonable? Did processes operate as expected? Were key players able to carry out their duties? Were there any unintended effects of the program? Qualitative approaches have the advantage of allowing for more diversity in responses as well as the capacity to adapt to new developments or issues during the research process itself (Babbie 2001).

\section{Background Information of the Nkonkobe Youth Advisory Centre}

The Nkonkobe Youth Advisory centre is fully funded by Umsobomvu Youth Fund to provide financial services for aspiring youth entrepreneurs. The centre also offers the following programs namely job seekers program, entrepreneurs, career advisor program, basic Computer Skills, Outreach, information towards developing the youth. The following is a brief background on the programs offered by the centre and lastly the job seekers program will be mentioned since this research was mostly interested in it.

\subsection{Entrepreneurs program}

This program is for those youths who are interested in entrepreneurship and are not interested in being employed by an individual or organisation. These youths come up with projects of their own either as individuals or as a group. Their project is then taken to relevant funders such as the Umsobomvu Trust Fund for review. After the review, when the projects look promising the youths are then given funds and an individual who will assist them with the project as a facilitator only not as a member of the group running the project.

\subsection{Career advisor program}

The career advisor program majors in helping the youths who are studying and who are eligible for formal employment with career advice. Officials from the youth centre visit mostly high schools and colleges in the Municipality. They advise high school students and those in colleges on choosing career paths that are in demand from most organisations the centre interacts with. High school students are advised to major in subjects that will give them an opportunity to do those degrees that fall under the category of scarce skills. Such degrees include engineering, mechanics, chemistry, medicine and computer science among others. Those that are already enrolled at a tertiary institution are advised to do short courses that will make their degrees to be lucrative.

\subsection{Basic Computer Skills}

This program offers basic computer skills to youths who do not have the technical knowledge of computer operation. Youths are taught basic computer skills such as Microsoft word and Microsoft excel and also how to surf on the internet. This is done so as to help them to get better jobs since such skills are needed by employers. However, the centre is facing a problem when it comes to offering such services because of lack of computers, time and staff to train the youths. Most youths do not possess such basic computer skills rendering this program a crucial program because it is a need. The officials stated that they are busy most of the times and do not have enough time to teach the youths basic computer skills since they can only train two people at a time because of lack of computers as well.

\subsection{Outreach program}

Since the centre is new and has not been operating for long, most youths are not aware of the centre. This program was put in place for such reasons. It is one of the first programs that the officials stated that they spent much of their time on. Officials stated that when the centre started operating they were not in office most of the time because they had to go out and advertise the centre which is quite reasonable. Officials from the centre seem to have underestimated the importance of the outreach program as they have stopped advertising the centre with an assumption that youths are now aware of the centre. This assumption is wrong because from this research it was found that most of the youths are not aware of the centre and only $1 \%$ of the youths stated that they knew about the centre from the outreach program. The remaining 
99\% heard about the centre from their peers or they just came across it when they visited the municipality for other services.

\subsection{Information program}

Unemployment is not the only challenge that youths are facing. There are other major challenges faced by the youths such as HIV and AIDS, drug abuse and teenage pregnancy among others. This centre also offers information concerning safe sex, abstinence from sexual activities and drugs. Since most youths in the municipality are not employed as stated in earlier on, there is crime in the municipality because of that. Officials in the municipality give information to the unemployed youths on how to deal with the frustrations that goes with unemployment. Officials in the centre also help youths with writing their curriculum vitae and also with information on how to conduct and prepare themselves for interviews. The centre also assists the youths who passed matriculation with bursaries and grants applications. Companies, organisations and universities such as Fort Hare among others, offer bursaries to these youths who are eligible for enrolment at a tertiary institution. Students who qualify for such enrolment go to the centre in search of information on scholarships, bursaries and grants that the centre might have received from these above mentioned institutions.

\subsection{Job seekers' program}

Much emphasis was given to this program since the main aim of the study was to assess its effectiveness towards promoting the employment of the youth. From the interviews the researcher held with officials from the youth advisory centre concerning what the job seekers program entails, the officials stated that the job seekers program seeks to achieve two goals. These goals are listed below

- to promote the employment of the unemployed youth and thereby reduce unemployment and

- to help those who are employed to get better positions.

\subsection{Promotion of employment to the youth}

The officials from the centre stated that the job seekers' program mainly addresses the challenge faced by the youths in the municipality and that is unemployment. The centre interacts with different organisations and employers that offer employment to the youths. Job opportunities and application forms are found at the centre and the youths come to the centre to collect these forms. These forms range from learnerships, internships to both temporary and permanent job opportunities. The centre receives job vacancies from different departments such as construction, navy, South African police services, education and nursing among others.

One of the officials stated that they deal with different kinds of unemployed youths namely those youths who only have grade 11, those who passed grade 12, and those who have diplomas from different fields of study and lastly graduates who hold degrees from different fields of study also. Officials further stated that those youths who do not have matriculation face more challenges in finding a job than those who have grade 12. Since it is hard for youths who do not have matriculation face in attaining a job, they get learnerships since they do not need a lot of 'requirements' for one to be eligible.

The interview that the researcher held with these officials showed that these officials believe that the job seekers' program is helping the unemployed youth to a large extent. One of them stated that '... . We have a lot of success stories with the job seekers program....' However the unemployed youths' perspective on the program is contrary to that of the officials. Most youths when answering the questionnaires complained that they have not benefited from the job seekers program regardless of the fact that they have visited the centre several times to make applications for jobs, learnerships and internships.

Moreover, the youths were also complaining that most of the times when they visit the centre they found out that there are jobs that they would have qualified for but the due date for the applications would have elapsed. Most youths were skeptical about the officials themselves stating that they are guilty of nepotism. The youths stated that these officials are more concerned with their families, relatives and friends more than the community they are serving. Youths stated that these officials '.........banika ijob ngobuso......' meaning that officials are discriminative, they give jobs to those youths they are related to.

When asked whether the centre should continue despite all the above mentioned shortcomings, the youths showed that they want the centre to continue. They further stated that the centre should continue since there are 'others 
youths' who are benefitting from the centre. The youths however made it clear that they want new officials to work at the centre. Youths stated that the municipality should employ people who are not from the Nkonkobe municipality to avoid the issue of nepotism. According to the youth, since only youths from the Nkonkobe municipality can get jobs advertised through the centre then new officials from other places would not be able to be discriminative under such circumstances.

Moreso, youths complained that when they get to hear about job opportunities when they apply they are not given a feedback as to whether they got the job or not. The researcher then asked one of the officials why this is so and the official stated that the employers are the ones to blame since it is their duty to inform the applicants whether they got the job or not. One of the officials further stated that the issue of job opportunities is complicated because other municipalities 'rob' them by taking jobs that were meant for the Nkonkobe municipality and giving them to the youths in their own municipality.

Furthermore, youths felt that the age category of the youth is too wide, in their opinion, it needs to be reduced and concentrated on a realistic target. The youths stated that as long as the youth age group still ranges from 14-35, the job seekers program would not be effective in promoting the employment of the youth. They suggested that the centre needs to target a reasonable category of youths for example those who are between the ages of 15-28. During the interview one of the officials mentioned that they sometimes go beyond their target group which is 14-35, to up to those who are aged 40 years old. This therefore, shows that the centre needs a fixed target group so as to be effective.

\subsection{Career development opportunities}

The centre also offers better positions to those youths who are employed but are seeking better positions that are better paying. The researcher then asked the officials whether it is reasonable for the officials to be helping youths who are employed already to get better positions whilst other youths are unemployed and most of them have not been employed for the past five years. Officials then stated that it is not their doing but it is the organisations that compel them to do so because of the job advertisements that they give them. The researcher was given some advertisement which the centre received from an organisation that needed young people who have experience in different fields, implicating that those who have not worked before do not qualify.

The researcher found that most youths are discouraged and have given up looking for employment because even the centre that they had put their hope in is not effective. When asked what they want done for them to be helped they stated that they want the government to come up with youth projects and others were of the opinion that since they cannot get employment, the government has to build them houses and give them grants to use for buying food and other basics.

A critical assessment of the Nkonkobe youth advisory centre shows that the centre is biased towards the youth in urban settlements. This is so because youths in rural areas are not aware of the centre hence cannot benefit from it. Youths in Alice where the centre is, were complaining that the centre does not advertise the available vacancies on time. Based on this finding, it shows that the youths in rural areas are at worst affected since they do not often visit the centre because it is far away from where they stay. The job seekers' program is a positive youth development program in theory and it can impact positively on the development of the youths if it can be implemented in a transparent manner.

The approach that is in place as of now by the Nkonkobe youth advisory centre is that youths are viewed as objects. This means that the centre is exercising control over the youth programs, deciding what programs are suitable for the youths. Youths do not own their own programs and as such this has led to the ineffectiveness of the job seekers' program.

Positive youth development is about including youths in their own development by including them in their programs in the initial stage. Youths need to come up with their own programs that they view as positive, youth development programs cannot bring positive results if they are imposed on the youths. Therefore, this points that youths in the municipality should be consulted before youth development programs are implemented in order to get their view on the programs. Youths should be viewed as a resource and as such they will be involved in the planning, implementation and evaluation of their own programs. When such a strategy is used programs and activities will be for and with the youth leading to positive youth development.

The researcher also found that most youths were not aware of the centre especially those in rural areas. Those who knew about the centre they either heard it from their friends or saw the poster on the door while passing by. Officials stated in the interview that they have outreach programs and they were very positive that the youths are aware of the centre. The youths however sang a different song from those of the officials. 


\section{Conclusion}

Youth unemployment is a major challenge that youths in the Nkonkobe Municipality like any other youths from other municipalities in South Africa are faced with. The researcher noted that the youth advisory centre at Alice is not effective in addressing the youths' major challenge which is unemployment. It has only managed to identify the fact that the majority of its young people have a matriculation qualification. This qualification gives the youths an opportunity to enroll at a tertiary institution and as such they become qualified in specific fields. The centre is very much aware of the abilities that the youths have and this is a good starting point for the centre to be of better help to the youths in future.

Another conclusion that the researcher found is that the youths are not willing to come up with projects of their own development. As a result they are dependent upon the government to come up with projects on their behalf. Therefore, this shows a dependency syndrome from the youth which is not favourable for the youths since they are leaders of tomorrow, they have to start now to be creative and come up with projects that will help them develop. Youths made it clear that they are dependent upon the government for job creation. This is because the majority of the youths who answered the questionnaires pointed to the government intervention as the only solution to their unemployment problem.

Another observation is that the centre is under staffed and as such cannot operate in its full capacity to address the needs of youths. Only two officials are working at the centre and they have to make sure that the different programs namely job seekers program, entrepreneurs, career advisor program, basic Computer Skills, Outreach, information are all offered to the youths. Such work load is too much for two people and it will lead to ineffectiveness of the centre. It is not possible that these officials can be able to render the much needed attention on the Job Seekers' Program (JSP) when they have other programs to deal with. This eventually led to ineffectiveness. In addition, the centre is under resourced. It only has two computers available for training the youth on computer literacy. This affects its ability to help the youth in alleviating unemployment since a few of them will be able to access the help of the centre.

Among other contributory factors, the issue of nepotism may also be blamed on the fact that the officials were alleged not to be giving enough time for outreach programs. The outreach programs are important as they make the youths to be aware of the available vacancies. Moreover, the Alice Youth Advisory Centre is not widely known to the youths. This does not paint a good picture about the centre because it must be known by the youths for it to be effective.

Shange (2002) states that the youths should not only be seen as beneficiaries of a program or project but should be centrally involved in it and "should be partners in their own development". Therefore, this means that officials in the centre should have included the youths in these programs before imposing them on the youths. Youths should be partners in their own development because by just being on the receiving end, it creates a dependency syndrome on the youths. If youths have been included from the word go, they would not have had so many issues to complain about the centre because they would have been included when it started.

Furthermore, the researcher found that the implementation of the job seekers program took a top down approach. This was highlighted by the beneficiaries who indicated that the job seekers' program has done little to ameliorate their plight whereas the officials are of the opinion that the program has helped the youths by providing them with job opportunities. In elaboration of their opinion, the youths expressed that there are some clandestine activities involved in the distribution of job opportunities. This is contrary to what Shange posits, that youths should be centrally involved in their development thereby eliminating any suspicion or opportunity of covert activities.

Another observation is that the youth officials and the youths' perspective about the job seekers' program are contrary. This shows that there is a crucial step that was omitted which was supposed to be implemented before the operation of the centre. The youths should have been included when programs where designed to view whether they have the same perception about the programs as do the officials. In addition, the officials should have made the job seekers' programs goals known to the youths. This is because none of the youths that answered the questionnaires knew that the job seekers' program also caters for those youths that are already employed and are seeking better paying jobs.

In a nutshell, the researcher came to the conclusion that youths did not receive accurate information about what a youth advisory centre is, when the officials did the outreach program. Some of the complaints that the youths were coming up with showed that youths misunderstand what Youth Advisory Centres (YACs) are. The National Youth Development Agency (NYDA) states that YACs are walk in centres where trained personnel provide information, counseling support, training and referral services to young people (NYDA, 2010). These YACs offer programs such as the job seekers' program that promote the employment of the youths. The definition of the YACs shows that once the youths become aware of the centre, it is their responsibility to visit the centre more often in search of jobs, internships and learnerships. 


\section{References}

As de Vos, Strydom H., Fouche C. B and Delport. 2005. Research at Grass Roots: For Social Sciences and Human Service Professions. South Africa: Van Schaik

Babbie E. 2001. The Practice of Social Research. Oxford University Press, New York

Bronfenbrenner, U., \& Morris, P. (1998). The ecology of developmental processes. In R.M. Lerner (Ed.), Handbook of child psychology: Vol.1. Theoretical models of human development ( $5^{\text {th }} \mathrm{Ed}$.). New York: Wiley.

Burns, N. and Grove, S. 1993. The practice of nursing research: conduct, critique and utilization (2nd ed). W.B. Saunders: Philadelphia, Pennsylvania, USA.

Centre for Youth Development and Policy Research. "What is Youth Development?" http://cyd.aed.org/whatis.html (accessed 23/08/10).

Checkoway, B et al Children and Youth Services Review 27 (2005) 1149-1162

Checkoway, B. (1998). Involving young people in neighborhood development. Children and Youth Services Review, 20, $765-795$.

Commnunity Youth Development: "A Definition in Four Parts" http://agexted.cas.psu.edu/fcs/dp/definition.html (accessed 09/09/10).

Davids et al. 2005. Participatory Development in South Africa: A development management perspective. Van Schaik Publishers, Pretoria.

Dewey, J. (1983). Experience and education. New York: Collier.

Fouche, C.B. and Deport, C. S. L. 2002. Introduction to the research process in De Vos, A. S (Edition), Strydom, Research at Grass Roots: For Social Sciences and Human Service Professions. South Africa: Van Schaik Publishers.

Guliwe (undated) Exploring the state of youth unemployment in South Africa: A Disaster in the making.

Hannabus 1983. The importance of user studies accessed from http://training.itcilo.org/actrav/courses on 23/09/2010

Jeppe, W.J.O. 1990. Training for development within the context of present-day development thinking. Africanus, 20(1\&2): 62-66

Korten, D.C. 1990. Getting to the $21^{\text {st }}$ century: voluntary action and the global agenda. West Harford: Kumarian Press.

National Youth Commission (2001): "National Youth Commission Strategy Statement",accessed from http://www.nyc.gov.za/media_documents.html on 11/08/10

National Youth Commission (2002): "National Youth Development Policy Framework (2002-2007)-Towards Integrated National Youth Development Initiatives and Programmes", accessed from http://www.nyc.gov.za/media_documents.html on 05/08/10.

National Youth Commission (2002): "National Youth Development Policy Framework (2002-2007)-Towards Integrated National Youth Development Initiatives and Programmes", accessed from http://www.nyc.gov.za/media_documents.html on 23/10/10.

National Youth Commission Act,1996 (Act 19 of 1996) accessed from http://www.pmg.org.za/files/docs/081014act.pdf on 23/10/10.

National Youth Development Agency website. 2010. Accessed from www.nyda.gov.za/index.php?option=com on 10/11/10.

Pennstate Family and Consumer Sciences (2000) 'Family or Youth Resilience and Policy' accessed from http://www.hsrc.ac.za/research/outputDocuments/2619 on 28/07/10.

Pittman, K, Irby M, Ferber T, (2000). Unfinished Business: Further reflections on a decade of Promoting Youth Development. Takoma Park, MD, International Youth Foundation.

Poole, A. (2005). Youth participation in drug prevention programs, Strasbourg: Pompidou Group, Council of Europe (accessed 09/09/10).

Raising Nevada (2000) "An Asset-based Approach to Helping Youth", http://www.raisingnevada.org (accessed 11/0810).

Sarantakos, S. (2002). Social Research. New York: Palgrave.

Schwartzman 1983. Handbook of family therapy training and supervision. New York: Guilford.

Shange, L. (2002) "A Guide to Implementing Integrated Youth Development Programs". Johannesburg: Youth Development Network.

Sigudhla M. A, (2005) Perspectives on Youth and Governance in Africa sadcyouth@yahoo.com (accessed 20/09/10).

Statistics South Africa accessed from http://www.statssa.gov.za (on 09/09/10).

Strydom 2002. Critical literacy: context, research, and practice in the K-12 classroom. Sage Publications.

University of Nevada, "What is Youth Development? A Parent's Guide to Youth Programs", http://www.unce.unr.edu/publications IFS02/FS0288.pdf accessed on 23/08/10

US Department of Health and Human Services (2002) "Towards a blueprint for youth: making positive youth development a national priority", from http://www.acf.hhs.gov/programs/fysb/youthinfo/brochure.pdf (accessed 12/08/10).

White Paper for Social Welfare, 1997 (August, 1997) accessed from www.treasury.gov.za/legislation/mfma/guidelines/whitepaper.pdf on 09/09/10

White Paper on Local Government, 1998 (9 March 1998) accessed from www.polity.org.za/polity/govdocs/white_papers/social971.html on 09/09/10 